\title{
The rediscovery of Strobilanthes tubiflos (Acanthaceae) in north east India
}

\author{
John R. I. Wood ${ }^{1,2}$ (D), Dipankar Borah ${ }^{3,4}$ \& Momang Taram ${ }^{3}$
}

Summary. The recently rediscovered Strobilanthes tubiflos (C.B.Clarke) J.R.I.Wood is fully described for the first time. A key and photographs are provided to enable identification of similar species found in north east India. The rediscovery of $S$. tubiflos is discussed in the context of the botanical exploration of the region and the implications for conservation.

Key Words. Conservation, key, taxonomy.

\section{Introduction}

As understood here, Strobilanthes Blume consists of around 400 species, thus making it the second largest genus in Acanthaceae (Mabberley 2017) after Justicia L. Historically there has long been uncertainty and disagreement about the limits of Strobilanthes with Nees (1832, 1847) and later Bremekamp (1944) dividing the Strobilanthinae sensu Bremekamp (1944) into many smaller genera whereas the opposite tendency was seen in publications by Anderson (1867), Clarke (1884), Terao (1983) and others. Our concept of the genus coincides with that of Terao (1983) who was the first to suggest that all species in the Strobilanthinae should be treated in a single genus. However, it is only since molecular studies have shown these segregate genera were nested within Strobilanthes (Moylan et al. 2003) that the broad concept of Strobilanthes has been generally accepted (Deng et al. 2006; Wood \& Scotland 2009; Hu et al. 2011; Wood 2014; Deng 2019).

Despite its species richness, Strobilanthes is almost entirely restricted to tropical and subtropical Asia and is essentially a genus of hill forest enjoying a monsoon climate. In India, there are two centres of diversity: the central and southern parts of Peninsular India, from where about 65 species are recorded, and the Himalayas and hills of NE India with approximately 85 species. These two regions are separated by the Gangetic plain and have quite distinct Strobilanthes floras (Wood 1994: 202) with only one or two weedy species occurring in both regions. Species numbers rise rapidly along the Himalayan chain from west to east, one species is known from Afghanistan, 23 from Nepal, 30 from Bhutan (Wood 1994), but around 85 are found in the NE corner of India in the small eastern states of Arunachal Pradesh, Assam, Meghalaya, Nagaland, Manipur, Mizoram and Tripura (unpublished information).

Although the Khasi Hills of Meghalaya and the lowlands of Assam were relatively well-known to botanists in the $19^{\text {th }}$ century, other areas of this north eastern region were rarely visited and poorly known botanically throughout the $19^{\text {th }}$ and $20^{\text {th }}$ centuries. New plant records were associated with major expeditions, such as those recorded by Burkill in the Abor Hills in 1911, or with adventurous botanists and plant hunters, such as William Griffith and Frank Kingdon Ward. A large number of the species collected in the $19^{\text {th }}$ and early $20^{\text {th }}$ century were not recollected for many years after the end of the colonial era. However, in the last fifteen years almost all have been rediscovered and photographed by Indian botanists (Wood 2016), amongst whom the second author, Dipankar Borah has played an important role.

One of Griffith's discoveries in 1836 was Strobilanthes tubiflos, which was described as a variety of Strobilanthes petiolaris by Clarke (1884). It was subsequently collected by Kingdon Ward in March 1949 but there was no further evidence of its survival until it was rediscovered by Dipankar Borah and Momang Taram in February 2020. As this is a species that has never been fully described or illustrated, a full description is provided below together with photographs and information on its habitat and conservation status.

Strobilanthes tubiflos (C.B.Clarke) J.R.I.Wood, Edinburgh J. Bot. 52: 264 (1994).

\footnotetext{
Accepted for publication 28 October 2020. Published online 5 May 2021

1 Department of Plant Sciences, University of Oxford, South Parks Road, Oxford, OX1 3RB, UK.

2 Honorary Research Associate, Royal Botanic Gardens Kew, Richmond, Surrey, TW9 3AE, UK. e-mail: jriwood@hotmail.com

3 Department of Botany, Rajiv Gandhi University, Rono Hills, Doimukh, 791112, Arunachal Pradesh, India.

4 Department of Botany, Goalpara College, Goalpara, 783101, Assam, India.
} 
Strobilanthes petiolaris var. tubiflos C.B.Clarke (1884: 458). Type: India, Arunachal Pradesh, Lohit, "Ghalooms", Griffith Kew Distribution No. 6095 (lectotype K000883127 chosen by Wood (1994: 264).

Perennial herb with fibrous roots; stems weakly quadrangular, sulcate, bifariously pubescent with pubescence in hollows, upwardly some hairs gland-tipped, glabrescent especially below, brownish when dry. Leaves petiolate, lamina $4.5-16 \times 1.8-9 \mathrm{~cm}$, \pm elliptic to oblong-elliptic or ovate-elliptic, apex acuminate, base broadly cuneate and then tapering onto the petiole, margin (serrate-)dentate, glabrous, cystoliths prominent on both surfaces, adaxially rugose, glabrous, abaxially paler, pubescent on veins to subglabrous, lateral veins $6-10$ pairs; petioles up to $4 \mathrm{~cm}$ long. Inflorescence of simple or sparingly branched, axillary and terminal spikes mostly $2.5-5.5 \mathrm{~cm}$ long, these arising from the upper leaf axils; peduncles $1-3.5 \mathrm{~cm}$, glabrous (to thinly glandular pilose); rachis pubescent; bracts at branching points resembling small subsessile leaves, reduced to $7 \times 4 \mathrm{~mm}$; floral bracts $5-6 \times 3-3.5 \mathrm{~mm}$, obovate-spathulate, rounded to emarginate, yellow-green, densely covered in yellow-green, sticky, sessile and stipitate glands, bracteoles $4 \times 1.5 \mathrm{~mm}$, oblanceolate, obtuse, indumentum as for floral bracts; calyx subequally 5-lobed to base, lobes linear, $5.5-6.5 \times$ c. $1 \mathrm{~mm}$, usually slightly exceeding bracts, comose; corolla $2.75-3 \mathrm{~cm}$ long, blue (violet fide Kingdon-Ward) with white basal tube, funnelshaped, shallowly 5-lobed, lobes subequal, c. $3 \times 5 \mathrm{~mm}$, rounded, the exterior pubescent; stamens 2, filaments c. $15 \mathrm{~mm}$ long, white, anthers $2 \mathrm{~mm}$ long, acute, included; staminodes 2, $12 \mathrm{~mm}$ long, white; pollen c. $86 \times 64 \mu \mathrm{m}$, ellipsoidal, tricolpate, pseudocolpate; style c. $20 \mathrm{~mm}$ long, white, included; disc glabrous, ovary comose. Capsule $6 \mathrm{~mm}$ long, oblong, 4-seeded, comose; seeds $2 \times 2 \mathrm{~mm}$, lenticular, appressed pubescent with mucilaginous hairs. Fig. 1.

HABITAT \& DISTRIBUTION. Endemic to Arunachal Pradesh in NE India, where it is found in the Upper Brahmaputra river valley by the Lohit, and Siang (Dihang) rivers (or their tributaries), growing on partially shaded rocky banks above streams at altitudes below $600 \mathrm{~m}$.

SPECIMENS EXAMINED. INDIA. Arunachal Pradesh: Mishmi hills, [Lohit Distr.], banks of the Lohit R., near "Ghalooms", W. Griffith Kew Dist. 6095 (lectotype K 000883127); Mishmi hills, W. Griffith Kew Dist. 6103 (K 000883128/9); Mishmi, [Lohit Distr.], Kamlang R., in jungle sere, along the river bank, $750 \mathrm{ft}$ (c. $230 \mathrm{~m})$, 14 March 1949, F. Kingdon-Ward 18409 (BM, NY); East Siang Distr., Pasighat, near to Sirki waterfalls, $28^{\circ} 06^{\prime} 09.2^{\prime \prime} \mathrm{N} 95^{\circ} 15^{\prime} 42.8^{\prime \prime} \mathrm{E}, 500 \mathrm{~m}, 21$ Feb. 2020,
Dipankar Borah Ẽ Momang Taram 10356; ibid., 10357; ibid., 10359 (Herbarium of Rajiv Gandhi University, Arunachal Pradesh).

CONSERVATION ASSESSMENT. Strobilanthes tubiflos is known from two or possibly three locations in the region where the Brahmaputra River emerges from the Himalayas. We have no information about the Lohit location except that it was near the Kamlang River, but it probably lies within the Kamlang Wildlife Sanctuary (27 $40^{\prime} \mathrm{N} 96^{\circ} 26^{\prime} \mathrm{E}$ approx.), a protected area established in 1989. Dipankar Borah and Momang Taram's discovery of a new population in the Siang (Dahang) valley extends the known distribution of Strobilanthes tubiflos. The Siang location is represented by a single population of about 150 individuals growing on rocky slopes and on pebbled ground resulting from a landslide near the Sirki waterfalls. The area is shaded for about half the day. It is associated with scattered plants of Phoenix rupicola $\mathrm{T}$. Anderson, Impatiens sp., Pandanus sp., Ficus sp., etc. at an altitude of just above $500 \mathrm{~m}$. Although the population does not seem to be expanding, no direct threats were observed. It is to be hoped it is relatively secure in this habitat but it could be threatened by landslides, which are common here, or, possibly, by future hydro-electric projects.

Further populations of Strobilanthes tubiflos may be found in this poorly known region, where other branches of the Brahmaputra River, such as the Dibang, emerge from the mountains, so this species should be classified provisionally as Data Deficient within IUCN (2012). It may well prove to be vulnerable (VUL) as suggested by Wood et al. (2003) because of the small number of populations, but there is insufficient evidence for a firm categorisation at the present time.

NOTES. Strobilanthes tubiflos was originally described under the name $S$. petiolaris var. tubiflos C.B.Clarke (1884) and belongs to a group of species placed by Bremekamp (1944) in a separate genus, Sympagis (Nees) Bremek. Strobilanthes tubiflos is perhaps closest to S. kachinensis J.R.I.Wood \& J.R.Benn. from Myanmar which also has only two fertile stamens but differs in the shorter obovate-spathulate, rounded to emarginate floral bracts $5-6 \times 3-3.5 \mathrm{~mm}$ (not oblong, acute $6-12 \times 3.5 \mathrm{~mm}$ ) and globose, rather than ellipsoid pollen. The bracts of the two species are illustrated and compared in Wood et al. 2003: 169.

Wood et al. (2003) discussed the Sympagis group and listed the nine species that occur in NE India (Wood et al. 2003: 141) together with their most recent Indian record: Strobilanthes asymmetrica J.R.I.Wood \& J.R.Benn., S. brunoniana Nees (Fig. 2E, F), S. frondosa J.R.I.Wood (Fig. 2C, D), S. himalayana J.R.I.Wood (Fig. 2H), S. imbricata 

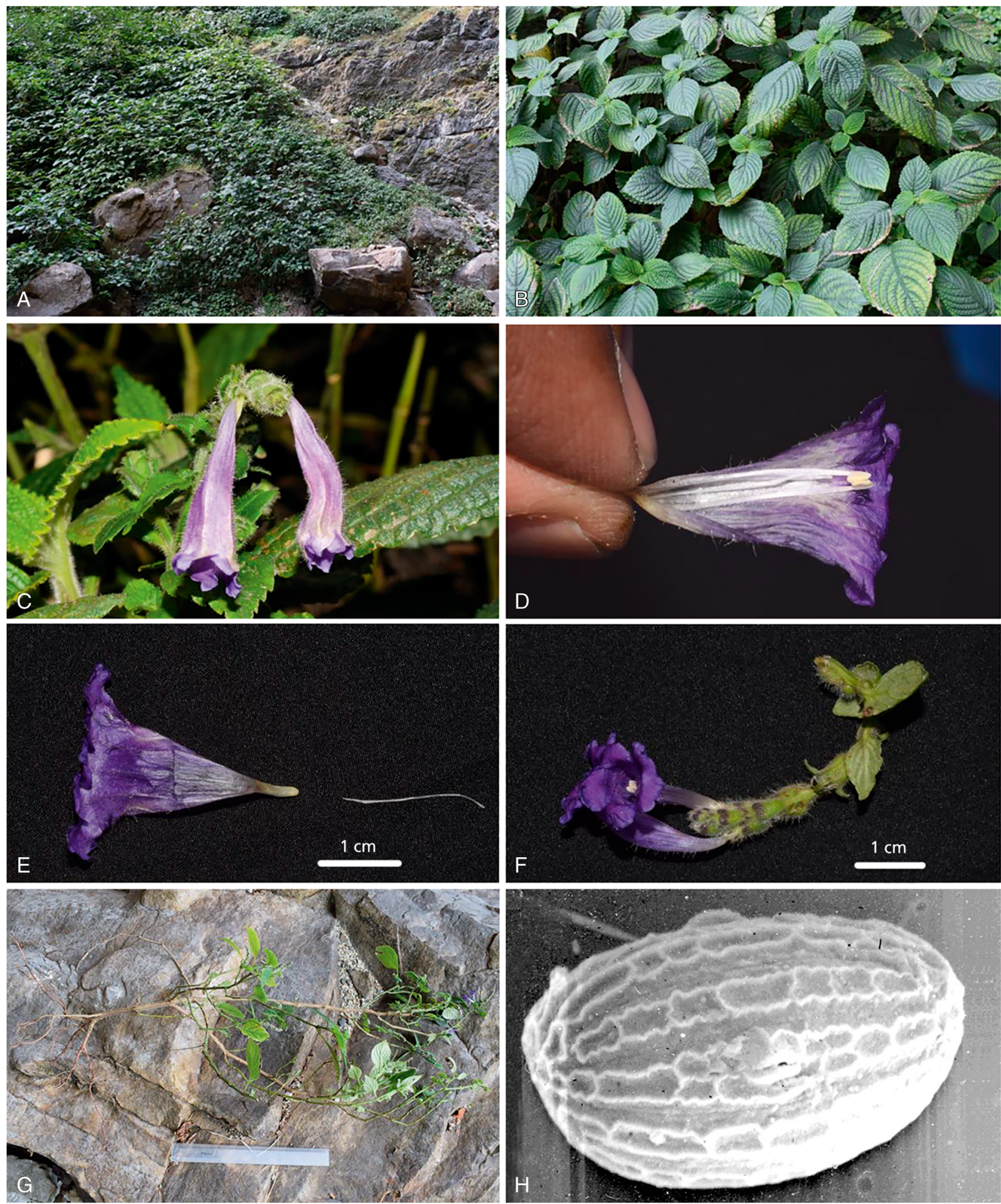

Fig. 1. Strobilanthes tubiflos. A habitat; B population density; C inflorescence; D corolla opened out to show stamens; E corolla and style; F inflorescence showing bracts; G habit; H pollen. A - G Dipankar Borah \& Momang Taram 10356; H Griffith 6095. PHOTOs: A - G DIPANKAR BORAH; H J. R. BENNETT. 

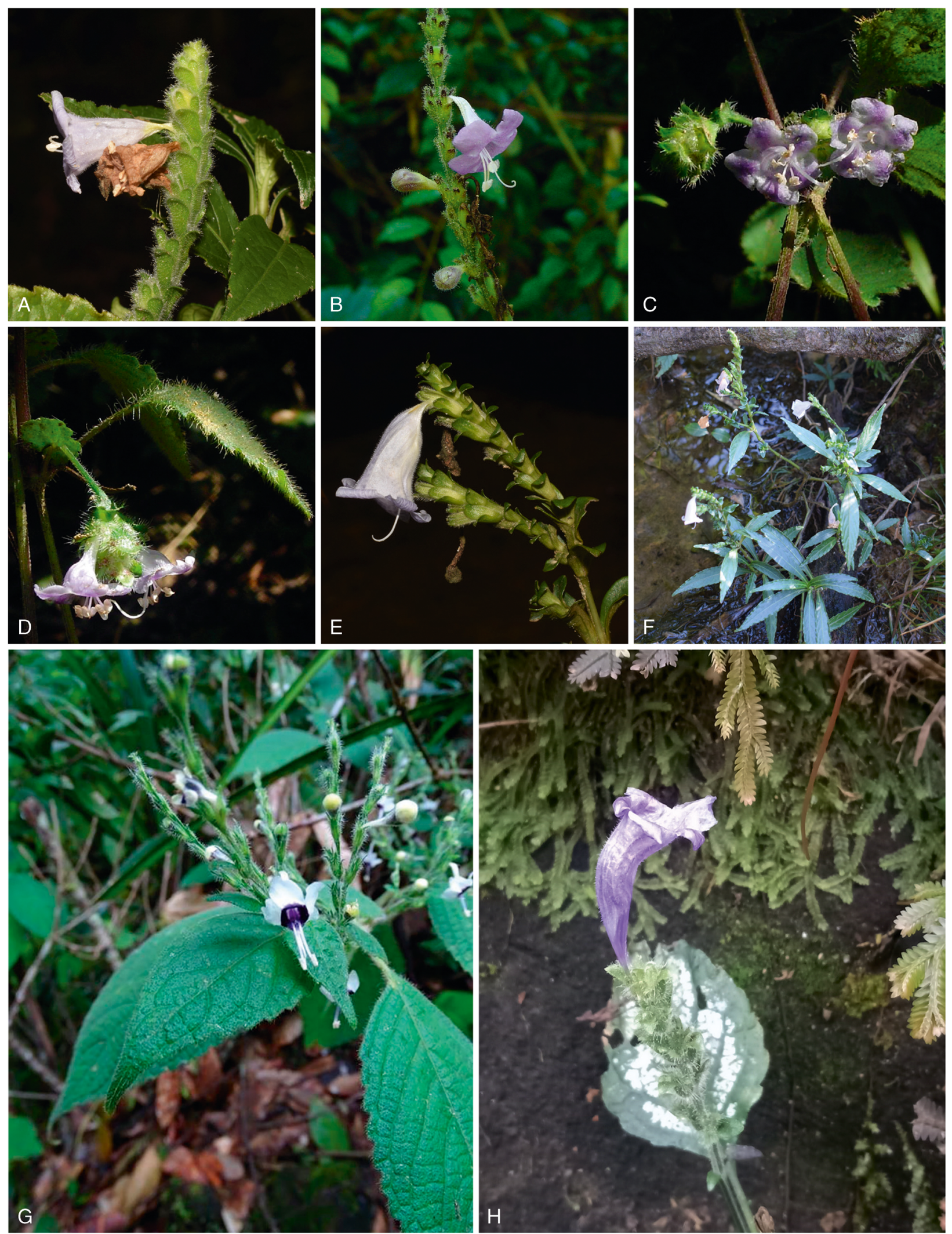

Fig. 2. Species of the Sympagis group of Strobilanthes from north east India. A Strobilanthes monadelpha; B S. maculata; C - D S. frondosa; E - F S. brunoniana; G S. khasyana; H S. himalayana. PHOTOS: A, E, F DIPANKAR BORAH; B, C, D PRASHANT AWALE; G M. SAWMLIANA; H SHUVADEEP MAJUMDAR. 
Nees, S. khasyana (Nees) T.Anderson (Fig. 2G), S. maculata (Wall.) Nees (Fig. 2B), S. monadelpha Nees (Fig. 2A) and S. tubiflos (C.B.Clarke) J.R.I.Wood (Fig. 1). The group is characterised by its spicate inflorescence with imbricate, bracteate flowers and subglobose, triporate pollen usually lacking pseudocolpi, although $S$. tubiflos differs in shape from this typical pollen. The Indian species have 4-seeded capsules, the bracts are small and persistent and the calyx subequally 5 -lobed. These species can be separated by the following key:

Key to the species of the Sympagis group occuring in north east India

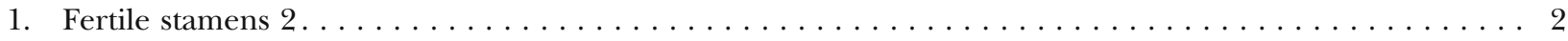

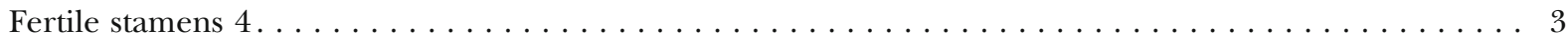

2. Spikes axillary, several in each axil; stamens strongly exserted; corolla white (Meghalaya) . . . . . S. khasyana Spikes solitary in each axil or terminal; stamens at most weakly exserted; corolla blue (Arunachal Pradesh)

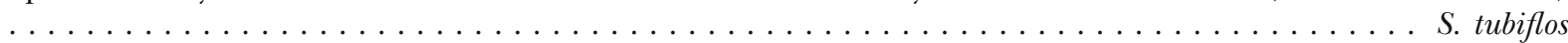

3. Leaves narrowly oblong-lanceolate, $<2.5 \mathrm{~cm}$ wide, entire or undulate (Meghalaya) . . . . . . . S. brunoniana

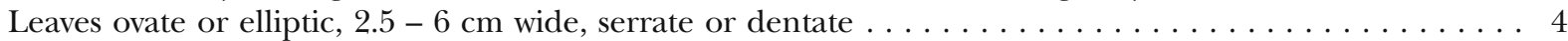

4. Leaves roughly pilose; bracts shouldered with distinct lateral tooth; inflorescence short, $<2 \mathrm{~cm}$ long, often

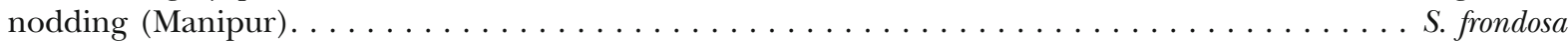
Leaves glabrous to thinly pubescent; bracts entire, inflorescence elongate, usually $>2 \mathrm{~cm} \operatorname{long} \ldots \ldots \ldots$

5. Inflorescence much shorter than the subtending leaves; stems commonly winged (Manipur) . . . S. imbricata Inflorescence as long as or longer than subtending leaves; stems not winged . . . . . . . . . . 6

6. Strongly anisophyllous plant with very asymmetric leaves; corolla white (Manipur, Mizoram). . S. asymmetrica Isophyllous plants with nearly symmetrical leaves; corolla blue, rarely white $\ldots \ldots \ldots \ldots$

7. Corolla $2-3 \mathrm{~cm}$ long; leaves commonly white-blotched (Darjeeling area) . . . . . . . . . . S. himalayana Corolla $<2 \mathrm{~cm}$ long; leaves white-blotched or not $\ldots \ldots \ldots \ldots \ldots$

8. Bracts narrowly obovate; flowers imbricate; leaves not white-blotched; corolla funnel-shaped (Meghalaya). . S. monadelpha Bracts obovate; flowers separate; leaves usually white-blotched above and purplish beneath; corolla subcrateriform $($ NE India $) \ldots \ldots \ldots \ldots \ldots \ldots \ldots \ldots \ldots \ldots \ldots \ldots$

When the species list was prepared by Wood et al. (2003), none of these nine species had been refound in India since 1950 (the more recent dates cited for Strobilanthes imbricata and S. frondosa were from Myanmar and Bhutan, respectively). However, since 2003, all these species, except $S$. imbricata, have been refound in India and the first author has seen photographs in every case. Happily, this indicates that comments by Wood et al. (2003) that three of these species might be extinct were premature but even today there is still little information about the size of the populations of individual species or threats to their existence so it remains impossible to carry out accurate conservation assessments.

\section{Acknowledgements}

We wish to thank Prashant Awale, M. Sawmliana and Shuvadeep Majumdar for permission to use photographs of Strobilanthes in this paper. They and a number of other colleagues have contributed to significant advances to our understanding of the genus in northern India in recent years. We also thank Jon Bennett for the pollen photo and John Baker for help in arranging the plates.
Open Access This article is licensed under a Creative Commons Attribution 4.0 International License, which permits use, sharing, adaptation, distribution and reproduction in any medium or format, as long as you give appropriate credit to the original author(s) and the source, provide a link to the Creative Commons licence, and indicate if changes were made. The images or other third party material in this article are included in the article's Creative Commons licence, unless indicated otherwise in a credit line to the material. If material is not included in the article's Creative Commons licence and your intended use is not permitted by statutory regulation or exceeds the permitted use, you will need to obtain permission directly from the copyright holder. To view a copy of this licence, visit http://creativecommons.org/licenses/by/4.0/.

\section{References}

Anderson, T. (1867). An Enumeration of the Indian species of Acanthaceae. J. Linn. Soc., Bot. 9: 425 526.

Bremekamp, C. E. B. (1944). Materials for a monograph of the Strobilanthinae. Verh. Kon. Ned. Akad. Wetensch., Afd. Natuurk., Sect. 2, 1: 1 - 305. 
Clarke, C. B. (1884). Acanthaceae. In: J. D. Hooker, Flora of British India 4: 387 - 558. L. Reeve \& Co, London.

Deng, Y. F. (2019). Transfer of the Philippine species of Hemigraphis Nees to Strobilanthes Blume (Acanthaceae). Phytotaxa 404 (5): 1 - 3. https:// doi.org/10.11646/phytotaxa.404.5.3

, Wood, J. R. I. \& Scotland, R. W. (2006). New and reassessed species of Strobilanthes (Acanthaceae) in the flora of China. Bot. J. Linn. Soc. 150: 369 - 390. https://doi.org/10.1111/ j.1095-8339.2006.00473.x

Hu Chia-chi, Deng Yunfei, Wood, J. R. I. \& Daniel, T. F. (2011). Acanthaceae. In: Z. Wu \& P. H. Raven (eds), Flora of China Vol. 19: 369 - 477. Science Press, Beijing; Missouri Botanical Garden Press, St. Louis.

IUCN (2012). Guidelines for application of IUCN Red List Criteria at Regional and National Levels. International Union for the Conservation of Nature, Cambridge \& Gland.

Mabberley, D. J. (2017). Mabberley's Plant Book. Cambridge University Press, Cambridge.

Moylan, E. C., Bennett, J. R., Carine, M. A., Olmstead, R. G. \& Scotland, R. W. (2003). Phylogenetic relationships amongst Strobilanthes s.l.: evidence from ITS, nrDNA, TraL-F cpDNA and morphology. Amer. J. Bot. 91: 724 - 735. https://doi.org/ $10.2307 / 4115715$

Nees Von Esenbeck, C. G. (1832). Acanthaceae Indiae Orientalis. In: N. Wallich, Plantae Asiaticae Rariores 3: 70 - 117. Treuttel, Würtz \& Ritter, London.
(1847). Acanthaceae. In: A. P. de Candolle (ed), Prodromus systematis naturalis regni vegetabilis 11: 46 519. Masson, Paris.

Terao, H. (1983). Taxonomic study of the genus Strobilanthes Blume (Acanthaceae). Generic Delimitation and Infrageneric classification. Unpublished $\mathrm{PhD}$ thesis, Kyoto University, Kyoto, Japan.

Wood, J. R. I. (1994). Notes relating to the flora of Bhutan: XXIX. Acanthaceae, with special reference to Strobilanthes. Edinburgh J. Bot. 51: 175 - 274. https://doi.org/10.1017/S0960428600000871

(2014). New names and combinations in Indian Acanthaceae. Novon 23 (3): 385 - 395. https:// doi.org/10.3417/2013046

(2016). The rediscovery of long-lost Acanthaceae from the Himalayan Region. Oxford Pl. Syst. 22: 16. https://herbaria.plants.ox.ac.uk/bol/Content/Projects/oxford/ops/ops22a.pdf

, Bennett, J. R. \& Scotland, R. W. (2003). Notes on Strobilanthes: the Sympagis group. Kew Bull. 58: 131 173.

\& Scotland, R. W. (2009). New and little-known species of Strobilanthes (Acanthaceae) from India and South East Asia. Kew Bull. 64: 3 - 47. https:// doi.org/10.1007/S12225-009-9098

\section{Publisher's Note}

Springer Nature remains neutral with regard to jurisdictional claims in published maps and institutional affiliations. 